\title{
DEATH AND RESURRECTION OF COPYRIGHT BETWEEN LAW AND TECHNOLOGY
}

Marcella Favale ${ }^{1}$

Information and Communication Technology Law, Volume 23, Issue 2, 2014

The paper reviews copyright philosophical, economic and social justification confronted by the dematerialization of creative outputs. Digital Rights Management (DRM) is the tool implemented by copyright owners to adjust to the advent of the Digital Era. The claim is that DRM effectively addresses digital threats and market failures. If this is true, what is left of the role of copyright law in the digital environment?

This review suggests an argument for traditional copyright justifications to resist in the digital environment. As a consequence, digital tools as DRM need to be engineered according to these justifications, in order to preserve the balance between law and technology.

\section{Introduction}

The so-called Digital Era started when some copyright works lost their physical form and became "virtual". While analogue copyright works are bundled with their physical carriers, such as books, celluloid, vinyl disks, digital copyright works can leap from a carrier to another (CDs, DVDs, computer memory units) without losing their appeal. In consequence, the supply chain of artefacts and their distribution models have been revolutionized; and the process of dematerialization, as cloud computing ${ }^{2}$ shows, is far from being concluded.

In the light of such dramatic metamorphosis, many legal commentators envisaged scenarios of substantial change in copyright legislation. ${ }^{3}$ Many advocate an increase in

\footnotetext{
${ }^{1}$ Senior Researcher at Bournemouth University: mfavale@bournemouth.ac.uk.

${ }^{2}$ Storage of data in a remote location accessible over a network. For a definition and in-depth explanation of cloud computing see generally W Voorsluys, J Broberg, R Buyya, 'Introduction to Cloud Computing' in R Buyya, J Broberg, A Goscinski (eds), Cloud Computing: Principles and Paradigms (Wiley Press, New York 2011) 1-44.

${ }^{3}$ Martin Kretschmer, for example, hypothesized a radical subversion of copyright law within a generation. He argues that the current legislation (American, European and International) is counterproductive and ineffective, because it hinders the diffusion of culture and information, whereas it should enhance it - and
} 
copyright protection: more rights for the owner, longer duration, and stricter enforcement. ${ }^{4}$ Others, on the contrary, champion internet freedom, right to access digital works, and Net neutrality. These are mostly civil rights organizations and supporters.

Part of the copyright literature endorses new technologies such as Digital Right Management (DRM) as the way to fix the imperfections of the market (market failures), which are worsened by the digital environment. In particular, digital works are easier to copy, and the quality of copies is virtually identical to that of the originals. This encourages free-riding behaviours, which are a cause of market failure. ${ }^{5}$

DRM, conversely, stems free-riding behaviours. It is a system of technical devices designed to assert and self-enforce copyright's exclusive rights, and therefore it reduces dramatically the costs of enforcement of copyright law (transaction costs). Therefore, according to its supporters, DRM successfully implements copyright in the digital world.

However, there is an argument against DRM. Some claim that this new form of technological protection threatens the rights of the users of copyright works. DRM in short is against the public interest because it unduly hinders access to copyright works. ${ }^{6}$ As a response to this tension, radical changes to copyright law have been

indeed repeatedly claims this in its declaration of intents. The author puts forward his vision: 'Within a generation [...] copyright laws will change, so as to be unrecognisable. There will be a short burst of exclusivity, encouraging fast exploitation, followed by a remuneration right for the lifetime of the creator. Criminal law will retreat to the traditional domain of unauthorised or deceptive commercial exploitation. As we reflect, digital copyright at the turn of the millennium will have marked the end of an era'. See M Kretschmer, 'Digital Copyright: The End of an Era', 25(8) EIPR 333-341, 341.

${ }^{4}$ See A Minassian, 'The Death of Copyright: Enforceability of Shrinkwrap Licensing Agreements', (1997) 45 UCLA L R 569-609, 21. He states that the diffusion of shrinkwrap licensing in computer software field will lead to the end of copyright regulations, at least for digital goods, which will be more and more contract-based.

${ }^{5}$ Among these, self-declared copyright optimist Paul Goldstein. See P Goldstein, 'The Future of Copyright in a Digital Environment' in PB Hugenholtz (ed), The Future of Copyright in a Digital Environment (Kluwer Law International, The Hague 1996), 236. See also TW Bell, 'Fair Use vs. Fared Use: The Impact of Automated Rights Management on Copyright's Fair Use Doctrine', (1998) 76 N C L Rev 557-620, 580. Both are discussed below in section 2.3.

${ }^{6}$ LR Patterson and WS Lindberg, The Nature of Copyright: A Law Of Users' Rights (University of Georgia Press, Athens GA 1991); NW Netanel, 'Locating Copyright within the First Amendment Skein', (2001) Stan L R 1. See below section 2.4. 
recommended. ${ }^{7}$ However, some commentators argue that a simple transposition of the traditional copyright principles to the digital environment would be sufficient. ${ }^{8}$

Clearly, the view that copyright is in need of modifications is based on the inapplicability of traditional copyright principles to the digital environment. This paper discusses this assumption. The question is whether and to what extent copyright protection has to be different in a digital environment; and what is the role of DRM within this mutation. To answer these questions, the paper reviews the philosophic, economic, and social justifications of copyright protection, their impact on the digital environment, and the role of DRM in relation to copyright justifications.

The analysis of the relevant copyright literature will suggest that fundamental principles grounding copyright preserve all their relevance in the digital environment. Interactions among copyright players might have changed, but the drivers behind these interactions are the same. Therefore, the rationale of the law is still valid, and it also applies to digital copyright tools.

\section{The Philosophical Justifications of Copyright}

\subsection{Locke: The Sweat of the Brow}

“The Labor of one's Body and the Work of his Hands, I may say, are properly his". On this statement, from John Locke's 'Two Treaties of Government', Common Law has built its concept of property. ${ }^{9}$ The origin of the market economy, based on strong

\footnotetext{
${ }^{7}$ PB Hugenholtz, 'Adapting Copyright to the Information Superhighway' in P B Hugenholtz (ed), The Future of Copyright in a Digital Environment (Kluwer Law International, The Hague 1996), 99; and PE Geller, 'Toward an Overriding Norm In Copyright: Sign Wealth', (1994) 159/3 RIDA 27, arguing that in the digital environment would not be enough to adapt old principles; we need a radical revision of copyright.

${ }^{8}$ See Netanel (n 5) 289-290. See also T Dreier, 'Copyright Digitized: Philosophical Impacts and Practical Implications for Information Exchange in Digital Networks', (1993) WIPO Harvard, available at <http://www.ira.uka.de/ recht/deu/iir/dreier/publications/dreier_Copyright_Digitized.pdf>32, accessed 15 February 2014.

9 J Locke (Peter Laslett), Two Treatises of Government (1680-1690) (Project Gutemberg), book II, Chapter 5, para.26.
} 
property rights, is rooted in Locke's theory on the reward of labour. At the core of this theory there is the exclusive right of the owner, a right-claim to exclude others from her goods, mirrored by the duty of the others not to invade the property space. Locke's ideas informed Common Law copyright principles, which asserted the concept of intellectual property as a property right. ${ }^{10}$ Lockean theories are suitable to justify and ground intellectual property rights. ${ }^{11}$ In fact, they are so suitable that they are sometimes mistakenly believed to have been developed in express defence of intellectual property. ${ }^{12}$

Locke's theory, however, justifies not only the exclusive rights of the author but also the entitlements of the user. ${ }^{13}$ The theory of the 'sweat of the brow' grants the owner a right to use, transfer, and exclude the others, but it also gives the public a right to use the remaining common, administered in regimen of equality, in order to give the community what is necessary to thrive and flourish.

More in detail, Locke argues that the labourer has a property right on a share of the common, but only if she leaves "enough and as good" of the rest of the common to the others. ${ }^{14}$ Other conditions to the exclusive property right in Locke's theory show the central role of the community: a) a state of great need, in which everyone has to share

\footnotetext{
${ }^{10}$ The point is made by Wendy Gordon, quoting a decision of the Supreme Court of 1984 (Ruckelshaus v. Monsanto Co. 467 U.S. 986, 10002-03 (1984). The judges held that intangible 'products of an individual's labor and invention' can be 'property' subject to the protection of the Takings Clause. See W Gordon, 'A Property Right in Self-Expression: Equality and Individualism in the Natural Law of Intellectual Property’, (1993) 201 Yale Law J 1533-1609, 1540.

${ }^{11}$ Justin Hughes applies Lockean provisions to both physical property and intellectual property. The provision, despite having been conceived with material goods in mind, is even more suitable for immaterial goods. See J Hughes, 'The Philosophy of Intellectual Property', (1988) 77 Geo L J 287-365, sections $\mathrm{B}, \mathrm{C}$ and $\mathrm{D}$.

${ }^{12}$ Gordon (n 9), 1540. See also Hughes (n 10) section C: 'Intellectual property systems, however, do seem to accord with Locke's labor condition and the "enough an as good" requirement. In fact, the 'enough and as good' condition seems to hold true only in intellectual property system. That may mean that Locke's unique theoretical edifice finds its firmest bedrock in the common of ideas'.

${ }^{13}$ Hughes (n 10) section C.

${ }^{14}$ Locke (n 8), para. 26.
} 
his lot with the more unfortunate $;{ }^{15} \mathrm{~b}$ ) the absence of waste. No fruit, venison, or land has to be left to perish underutilized, because this would damage the entire community. ${ }^{16}$

The interest of the community in Locke' theory seems to be prevailing over the interest of the individual. ${ }^{17}$ According to this theory, the community should freely use the abundance of the fruit of the earth to facilitate the creation of a social context in which all are peers. Locke imagined a community able to flourish in a regimen of equality, which needed a government only to keep the community safe. ${ }^{18}$

The common he was envisaging, it may be inferred, was not only made by physical objects, but also by immaterial goods: ${ }^{19}$ culture and knowledge. Mankind flourishing would have been impossible without passing on ideas and inventions from generation to generation. ${ }^{20}$ In the realm of intellectual property, the most obvious form of common is the "public domain"; ${ }^{21}$ that is, expressive works not -or no longer- protected by copyright.

Wendy Gordon sees the whole common as a possible object of property to the benefit of the public. Even more interestingly, she maintains that "the common would be an enforceable 'right to use' inhering in the public, and thus property". ${ }^{22}$ In the digital environment, the common is becoming more easily accessible thanks to the

\footnotetext{
${ }^{15}$ ibid. Book I, Chapter 4 para. 42.

${ }^{16}$ ibid. Book II, par 37, and Book II, par 38.

${ }^{17}$ Gordon mentions Olivecrona (1974), who argued that Locke ignored the concept of a claim-right; even more, that the concept was never mentioned or presupposed by Locke. She argues against this claim-right. See Gordon (n 9), 1553.

${ }^{18}$ Locke (n 8), book II para.123.

${ }^{19}$ Gordon (n 9), 1555.

${ }^{20}$ ibid, 1556.

${ }^{21}$ Hughes (n 10), part II, sec. C, para.3.

${ }^{22}$ Gordon, (n 9) 1555.
} 
Internet. But together with goods no longer protected by copyright, also copyright works are more easily accessible and reproducible. Understandably, rightholders are increasingly concerned that they might no longer be able to protect their copyright works in such an open environment. Therefore they implemented technological protection measures to enforce their exclusive rights.

Still, the common is formed by the duty-free areas represented by copyright limits. Those are copyright expiry, exhaustion, the idea-expression dichotomy, and copyright exceptions (or fair-use). The claim that the public has on the common a property right opposed to the property right of the owner suggests that copyright holders have to allow the public to access copyright works whenever copyright limits create an entitlement. This is valid also in a digital environment.

This claim is reinforced by a reference to the Lockean proviso. Gordon argues that according to the "enough and as good" theory, the owner can collect as much land and fruit as she is able to, but she is constrained by the duty of leaving to her peers "enough and as good" of the same land and fruit. ${ }^{23}$ In intellectual property language this means that the author can forbid others to read, listen, and watch her creation only if she leaves "enough and as good" knowledge and information to the community. ${ }^{24}$ This means that she has to comply with copyright limits.

In case of conflicts between the claims of the rightholder and the claims of the public on the common, Gordon argues, giving property rights to the former is conceptually wrong. ${ }^{25} \mathrm{~A}$ full property right excessively compresses the entitlement of

\footnotetext{
${ }^{23}$ Locke (n 8), Book II para.27. Wendy Gordon specifies that is not clear whether the proviso is a precondition to the formation of property or Locke reserves to deepen if property is able to evolve without the proviso conditions. She sides with the first option. See Gordon (n 9) footnote 167.

${ }^{24}$ Gordon maintains 'the public is owed compensation if courts or legislatures violate the proviso by creating private rights that impair the public's access to the common' but it is worth specifying that 'compensation is an unsatisfactory second best', because, when the protected interest is free speech, 'this aspect of the common is not fungible with pure economic benefit'. See Gordon (n 9), 1608-1609.

${ }^{25}$ On the necessity of -at least-tempered property rights in the common of immaterial goods, also Justin Hughes, who asserts that since creation of the mind are all interdependent among each other (because the
} 
the public. A liability right, not enforceable by injunction, is more appropriate. ${ }^{26}$ The grant of a natural property right to the owner would conflict with the public good because when an intellectual creation is disclosed to the public, more harm than good can derive from stopping the public from accessing it. ${ }^{27}$

How these principles translate in the digital environment? It is in the right of the owner to stop others from accessing her goods thanks to DRM? Is DRM the equivalent of a fence, a boundary, a property landmark? Real locks stop people from entering a private property without making difference among individuals. As a consequence, no lock or fence can be legally used if neighbours have trespass rights. If we had to apply to the digital environment the same rules that apply to the real world, no DRM should be implemented on copyright work, unless this DRM implements technical locks able to grant some usage allowances to entitled users. In short, DRM has to leave "enough and as good" of the copyright work to the public. But how can this be achieved in practice?

The fundamental difference between DRM and real locks is that DRM can potentially ${ }^{28}$ differentiate between people having or not having the right to access the good, but they are currently implemented in an indiscriminate manner; they impose the same access rules to all users without distinction. However, in order to leave "enough" access and usage allowances to the public (that is, greater allowances to beneficiaries of copyright limits) they must be implemented with sufficient flexibility. In cases where this flexibility is not allowed by the technology or where the implementation of a

progress of science and culture is based on creation/discoveries of the past), to grant an exclusive right to exclude will paralyse evolution. See Hughes (n 10), section C, para. 1.

\footnotetext{
${ }^{26}$ She calls it a 'stowaway' right: enforceable only against those who are willing to harvest where they have not sowed. See Gordon, (n 9) 1609.

${ }^{27}$ Gordon cites as an example the case of a major discovery in medical science which is kept secret, causing the death of hundreds of people. ibid, 1567.

${ }^{28}$ See P Akester, 'Technological Accommodation of Conflicts between Freedom of Expression and DRM: The First Empirical Assessment' (May 5, 2009). Available on SSRN: <http://ssrn.com/abstract=1469412 or http://dx.doi.org/10.2139/ssrn.1469412> 8 accessed 25 April 2014. The study shows that the technology to implement copyright exceptions on DRM exists, but it is not implemented by rightholders.
} 
flexible DRM is not economically viable, DRM should not be implemented at all. In fact, the emergence of DRM-free policies among digital music retailers seems to confirm this construct.

In conclusion, also in the digital environment copyright limits are there to ensure that the public gets enough and as good a share of the common - that is, sufficient access allowance to digital works. This means that also in the digital environment locks protecting the property cannot be used without limits. More in detail, as long as digital locks can be implemented in a way to respect the entitlements of the users, they must do so or they should not be implemented at all.

\subsection{Hegel: The Natural Right}

In common law countries copyright protection is mainly targeted at the commercial exploitation of the work. It is the right to reproduce and divulge copyright works. The circulation of the artistic work for the benefit of the community is the main goal. This is why copyright protection provides incentives to creation, by protecting the author. Conversely, in continental Europe copyright protection is mainly focused on the person of the author. ${ }^{29}$ The purpose here is to preserve the independence of authors from patrons, in order to promote free expression of ideas. That is why traditionally copyright is considered socio-centric in common-law countries and the droit d'auteur individualcentric in continental law. However, as it is suggested below, this is somewhat of a misconception.

The right of the author, in continental Europe, consists of personal rights and patrimonial rights. Personal rights are most commonly the right of paternity, integrity and disclosure; they are acquired at the moment of creating the work and are generally

\footnotetext{
${ }^{29}$ J Holyoak and P Torremans, Intellectual Property Law (6th ed. OUP, Oxford 2010) 215.
} 
eternal and not waivable. ${ }^{30}$ Patrimonial rights (reproduction, communication, distribution, etc.) allow the commercial exploitation of the work. The droit d'auteur is based on the Hegelian ${ }^{31}$ theory of property right, which states that property is the expression of Man's personality. Will, Personality, and Freedom, according to Hegel, are the most important parts of every persona. The Will dominates Personality and Freedom. It is a vehicle through which Personality actualizes itself, translating Freedom to an external sphere. ${ }^{32}$ Freedom is the ability of Self-determination, and Selfdetermination is the ability to exercise one's influence on persons and things. The influence on the latter, in Hegel's conception, is the property right. The property right, therefore, is a type of freedom and can be exercised against the others. It is not only our imposition over the objects, but the first step towards self-actualization: ${ }^{33}$ the imposition of the Will upon the world. About intellectual property, Hegel says that 'attainments, eruditions, talents, and so forth, are, of course, owned by free mind and are something internal and not external to it, but even so, by expressing them it may embody them in something external and alienate them'. ${ }^{34}$ Therefore intellectual property is just another form of property: it is expression of the personality of the creator exactly like material property.

The doctrine of the droit d'auteur of civil law countries stemmed from French and German philosophy. In France - and in all jurisdictions inspired by French law - there is a "dualistic" 35 conception of author's right, which separate the personal side from the economic one. According to this doctrine, personal IP Rights are non-transferable,

\footnotetext{
${ }^{30}$ D Nimmer, Nimmer on Copyright (M. Bender, New York 1978) 1985.

${ }^{31}$ G Hegel, Philosophy of Right (1897), Thomas M. Knox (tr), (OUP, Oxford1942).

${ }^{32}$ Hughes (n10) 331.

33 ibid, 333.

${ }^{34}$ See Hegel (n 30) para.43.

${ }^{35}$ See P Goldstein, International Copyright, Principle, Law and Practice (OUP, Oxford 2001) 8.
} 
imprescriptible, indefeasible, and unlimited. Instead, patrimonial rights are transmissible, transferable, subject to forfeiture, and waivable. In countries like Germany, on the contrary, copyright law intertwines moral and economic right (they cannot be licensed separately) and provides both with the same regulation. ${ }^{36}$ Both rights are - formally - inalienable and both are limited in time. France and Germany, moreover, provide for a right of disclosure ${ }^{37}$ which is the right to disclose the work to the public. The right of disclosure, a personal right, is different from the right of distribution exquisitely commercial- which is granted by the EU legislation. ${ }^{38}$ Some European countries also provides for a right of withdrawal, ${ }^{39}$ which is the privilege to retire the work from circulation, on condition of compensating the producer.

The above suggests that the key feature of continental copyright is the authorcentrism. Protection is granted to the author because it is fair. It comes to him as a natural right. This concept seems opposite to common law copyright, which is eminently socio-centric. However, this traditional division between the continental droit d'auteur, natural and individualistic, and the Anglo-American copyright, commercial and social, is not as neat as it might appear. Jane Ginsburg, for example, in 'A Tale of Two Copyrights', through the analysis of revolutionary French and American case law, claims the two systems are more similar than generally admitted. Ginsburg finds that "French Revolutionary legislators, courts and advocates perceived literary property

\footnotetext{
${ }^{36}$ This is the Monistic theory. See A Rahmatian, 'Non-Assignability of Authors' Rights in Austria and Germany and its Relation to the Concept of Creativity in Civil Law Jurisdictions Generally: a Comparison with U.K. Copyright Law', (2000) 11(5) Ent L R 95-103, 98.

${ }^{37}$ Article L121-2 of the French Intellectual Property Code

${ }^{38}$ See for example Council Directive 2001/29/EC of 22 May 2001 on the harmonisation of certain aspects of copyright and related rights in the information society Official Journal L 167, 22/06/2001 P. $0010-$ 0019, Article 4. Also Council Directive 92/100/EEC of 19 November 1992 on rental right and lending right and on certain rights related to copyright in the field of intellectual property, Official Journal L 346, 27/11/1992 P. 0061 - 0066, Article 9.

${ }^{39}$ Article L121-4 of the French Intellectual Property Code.
} 
chiefly as a means to advance public instruction". ${ }^{40}$ Also Alain Strowel, in his work 'Droit d'auteur and Copyright', is sceptical about the "natural right" quality of the author's right from French tradition. The limited duration of such right, for example, shows that this notion has to be reconsidered. He argues that the difference between the French and the Anglo-American system resides more in interpreting the respective laws than in the ultimate justification of both regimes. ${ }^{41}$ This is confirmed by the fact that in continental Europe a few modifications have been made to the law to facilitate the commercial exploitation of the rights of the author. Some examples are the copyright protection for motion pictures, computer programs, and databases. ${ }^{42}$

The above arguments suggest that the author's right considered as an individualistic privilege, centred on the person of the author, comes from an incorrect interpretation of the droit d'auteur. SéverineDusollier makes the point extensively in her work on digital copyright. She recalls the theory of Habermas, who theorized the birth of a "sphere publique" in the $18^{\text {th }}$ century. The public sphere, according to this author, consists of private persons gathered in public spaces, forming "the public". The purpose of this "public reasoning" is to subject the State to a rational and public critique. This phenomenon, the author claims, gave birth to bourgeois society. Under the aegis of this public sphere, Dusollier argues, the continental author's right is born. The appearance of an educated social class, eager for culture and information, increased the demand for cultural goods, thus creating a market for them. Freedom and independence of the creators were deemed necessary, given that the main engine of this phenomenon was the

\footnotetext{
${ }^{40}$ JC Ginsburg, 'A Tale of Two Copyright: Literary Property in Revolutionary France and America', in B Sherman and A Strowel (eds) Of Authors and Origins (Clarendon Press, Oxford 1994), 158.

${ }^{41}$ A Strowel, 'Droit d'auteur and Copyright: Between History and Nature', in B. Sherman and A. Strowel (eds) Of Authors and Origins (Clarendon Press, Oxford 1994), 250-253.

42 ibid, 252.
} 
"public utilization of the reason". ${ }^{43}$ Ever since, she argues, the social function of the author's right was clearly established: the creation is meant for the public. Clearly, this is more similar in spirit to common law copyright than traditionally thought. ${ }^{44}$

The digital environment might appear to have brought some changes to this "public sphere" scenario. The implementation of DRM on copyright goods forces private access to the work, rather than its public fruition. The public, in the networked environment, is no longer gathered in a public space, but it is pulverised in a complex of private connections. It consists of a large group of consumers. Moreover, technical means ensure interaction and negotiations among copyright owners and users, thus translating regulations from a public to a private level. The law is no longer the source of copyright discipline. Rightholders set the rules through the contract. As an acute commentator noted, this suggests a trend towards copyright as a "private ordering". ${ }^{45}$ Private bodies are increasingly becoming the source of law in copyright. In fact, in order to enforce contract clauses without the help of the law, rightholders implemented DRM.

For the traditional balance between the author and the public, the implementation of technological protection measures is not without consequences. DRM can help to protect the independence of expression of the author, by granting her control over her work. But it can also hinder the function of the public sphere, which needs the information to circulate in order to inform the public discourse. ${ }^{46}$ This trade-off can be addressed by designing DRM systems that protect the author without paralysing public access to information and culture.

\footnotetext{
${ }^{43}$ S Dusollier, Droit d'auteur et protection des ouvres dans l'univers numérique (Larcier, Bruxelles 2005) 222.

${ }^{44}$ For the individualistic theory of the droit d'auteur, ibid 233, citing Desbois, Lucas and Caron.

${ }^{45}$ See Generally JE Cohen, 'Copyright and the Jurisprudence of Self-Help', (1998) 13 Berkeley Tech. L.J. 1089. See also D Friedman, 'In Defense of Private Orderings: Comments on Julie Cohen's "Copyrightand the Jurisprudence of Self-Help"' (1998) 13 Berkeley Tech L J 1151, in response to Cohen.

${ }^{46}$ Dusollier (n 42) 240.
} 


\section{The Economic Justifications of Copyright}

In the last decades copyright policies have been informed by economic theory. Copyright protection is shaped in the attempt to provide a balancing effect against the distortions of the market. Both copyright exclusive rights and copyright exceptions (or fair use) are justified by this market-adjusting function. The Digital Era impacted differently on economic justifications of copyright; it created new threats and new opportunities. DRM is devised to exploit the opportunities and tackle the threats. However, as discussed below, technological protection measures albeit useful to stem some market imperfections can also introduce new distortions in the market.

\subsection{The Economics of Copyright}

A pre-requisite for the functioning of market economies like the United States, Western Europe, Japan, Canada, and Australia, is the definition and protection of property rights. In a material world limited by physical boundaries, all resources are destined to be consumed, ${ }^{47}$ and only individual ownership ensures the best possible allocation of social assets. Private property rights, in short, are justified by a situation of scarcity. ${ }^{48}$

When those principles are translated to immaterial goods, some problems arise. Expressive works bear a few characteristics that are not common to physical assets. They are so-called "public goods". ${ }^{49}$ This has two major implications. First, intellectual creations are non-rivalrous; this is to say that a work of art can be enjoyed by an endless

\footnotetext{
${ }^{47}$ See generally G Hardin, 'The Tragedy of the Commons', (1968) 162 Science 1243-1248.

${ }^{48}$ This means that material resources are not endless.

${ }^{49}$ W Gordon, 'Fair Use as Market Failure: a Structural and Economic Analysis of the Betamax case and its Predecessors', (1982) 82 Col L R 1600-1657, 1611. The position is not uncontroversial. Paul Petrick, referring to digital music traded on physical carrier (music $\mathrm{CD}$ ), claims it to be excludable and rivalrous as any other commodity. See P Petrick, 'Why DRM Should be Cause for Concern: an Economic and Legal Analysis of the Effect of Digital Technology on the Music Industry', The Berkman Center for Internet and Society, Research publication n. 2004-09 (November 2004), at <http://cyber.law.harvard.edu/home/uploads/408/DRMPetrick.pdf> 30, accessed 12 April 2014.
} 
amount of people, without depleting the others of further enjoyment. Secondly, expressive works are also non-excludable, which means that it is not always possible to prevent people who have not paid for accessing the work to enjoy it. ${ }^{50}$ Those characteristics of copyright goods allow free-riding from people who benefit from the good without paying for its consumption. This is a market failure, because it will produce an under-supply of expressive works. ${ }^{51}$

Copyright law corrects those imperfections of the market, by ensuring to authors a bundle of rights (property-like rights) that compensates for the non-excludable nature of expressive works. ${ }^{52}$ In this way, it guarantees to the author the reward for her work, acting as an incentive for further creation. ${ }^{53}$ Fostering further creation, in turn, increases the common cultural patrimony and, more in general, public welfare.

The above theory derives from classical economics, tracking back to Adam Smith. ${ }^{54}$ However, in the last decades neoclassical economic theories have prevailed. According to neoclassical economy, strong copyright protection is instrumental in the social welfare, because it allows an optimal allocation of resources. In short, copyright protection corrects the public-good characteristics of expressive works, by turning them into vendible commodities. ${ }^{55}$ In an efficient market strong copyright protection would

\footnotetext{
${ }^{50}$ See generally TW Fisher, 'Reconstructing the fair use doctrine' (1988) 101 HLR 1661-1795.

${ }^{51}$ In a perfect market all costs and benefits of the transaction have to be born and negotiated by subjects involved in the transaction. Costs and benefit, in short, have to be internalised. If either costs or benefits are external to the transaction, the market fails again. So-called 'externalities', as in the case of free-riding, are one of the causes of market failure

${ }^{52}$ Fisher (n 49) 1612.

${ }^{53}$ See generally S Breyer, 'The Uneasy Case for Copyright: A Study of Copyright in Books, Photocopies and Computer Programs', (1970) 84 HLR 281-351;BW Tyerman, 'The Economic Rationale for Copyright Protection in Books: a Reply to Professor Breyer', (1971) 18 UCLA L R 1124-1125; G Palmer, 'A NonPosnerian Law and Economics Approach', (1989) Hamline L Rev, 287, and S Shavell and T Van Ypersele, 'Rewards Versus Intellectual Property Rights', (2001) 44 J Law Econ 525.

${ }^{54}$ See Netanel (n 5) 307; see also Gordon (n 9) 1590.

55 On the commodification of expressive works see generally P Samuelson, 'Copyright, Commodification, and Censorship: Past as a Prologue- But to What Future?', in N. Netanel and N. Elkin-Koren (eds) The Commodification of Information (Kluwer Law International, The Hague 2002) 63-77.
} 
produce the best possible expression of social value from copyright works, by hand of the subjects most suitable for the task ${ }^{56}$ Expressive works as vendible commodities will be produced and sold by people most able to get the highest values from them, thus allocating intellectual resources in an optimal manner. ${ }^{57}$

The economic model for this theory was provided by Landes and Posner in $1989 .{ }^{58}$ The authors maintain that the optimal amount of copyright protection should be higher for works that are socially more valuable. Those are the goods that create a higher surplus in society, obtained by subtracting the cost of production of the good from the social welfare per work. For Landes and Posner, increasing the protection above the optimal amount will increase the production of the work. However, initially, it will decrease the surplus for the public, because of the higher production cost. ${ }^{59}$ If over time, with the growth in income and technological advance, the market-size for an expressive work increases, and the cost of the production decreases, the welfare per work (and for the public) rises again. This demonstrates that an expansion of copyright protection is an advantage for the public welfare. This model served as a guide for many economists and legal copyright commentators, but it has also been widely contested and discussed. ${ }^{60}$

However, to achieve this result all conditions of perfect competition need to satisfied:

\footnotetext{
56 ibid, 68.

${ }^{57}$ According to Netanel, neo-classicists maintain that "copyright is primarily a mechanism for market facilitation". See Netanel (n 5) 309.

${ }^{58}$ WM Landes and PA Posner , 'An Economic Analysis of Copyright Law,' (1989) 18(2) J Leg Stud $325-$ 53.

${ }^{59}$ Because the production of more works leads to higher fixed costs/higher administrative and enforcement costs, therefore to a lower welfare per work, and in consequence to a lower general welfare.

${ }^{60}$ See for example CPB Netherlands Bureau for Economic Policy Analysis, 'Copyright protection: not more but different', CentraalPlanbureau, on line at< http://www.cpb.nl/eng/> at section 4.4, objecting that the model do not take into account information goods that are no longer valuable after short time, goods that could internalize the cost of possible unwanted copies, goods that is possible diversify between segment of the market and the effect of superstar (very famous creators); in all those cases, according to the report's compilers, the economic models suggest a reduced need for copyright.
} 
a) No externalities: all costs and benefits must be internal to the transaction (as to say that all costs and benefits must be borne by people with decision-making in the transaction);

b) No imperfect information: prospective customers need to have a perfect knowledge of all products available;

c) No transaction cost: i.e. cost borne though locating the contractors, bargaining and enforcing the contract;

d) No market power: i.e. imperfect competition, as in situations of monopoly, oligopoly, etc.

Of course, conditions of perfect competition do not exist in the real world. Therefore, whenever the market fails it is a task for legislators to take all necessary measures in order to correct it, by issuing regulations on consumer protection, and more generally by antitrust laws and tort law. ${ }^{61}$ The law corrects market imperfections in many ways: it provides means of enforcement and self-enforcement, thus helping lowering transaction costs; it obliges rightholders to provide information to customers; ${ }^{62}$ it perfects the negotiation process by providing (through expedients such as compulsory licensing) a solution to the refusal of the owner to negotiate, for non-economic reasons. ${ }^{63}$

The digital environment produced several changes to the above scenario. ${ }^{64}$ It aggravated the problem of non-excludability, thanks to the enhanced communication possibilities offered by the Internet. The easiness and quality of digital reproduction increased copyright "leaks" (i.e. free-riding - externalities), so to make rightholders fear

\footnotetext{
${ }^{61}$ Gordon (n 9), 1607.

62 ibid, 1610.

63 ibid, 1613.

64 The economical effects of these changes are yet to be ascertained by further research. See Stephen A. Merrill and William J. Raduchel (eds), "Copyright in the Digital Era: Building Evidence for Policy", Committee on the Impact of Copyright Policy on Innovation in the Digital Era, National Research Council of the National Academies 2013, available at <http://www.nap.edu/catalog.php?record_id=14686> 22, accessed 14 April 2014.
} 
for the recoup of their investments. In the digital environment the cost of reproduction of a copyright work is next to zero, and the reproductions are perfect substitutes of the originals. This produces an outbreak of copyright infringement, which prohibitively increases the cost of legal enforcement, and in consequence lowers the incentives for rightholders to produce copyright works.

Market imperfections, though, can also be eased by the advent of new technologies. The problem of imperfect information, for example, is eased by technological solutions, like search engines and databases. Transaction costs like those borne by locating the contractor and by carrying on negotiations can be alleviated by internet clearing houses, which provide information about reliability of contractors in real time. ${ }^{65}$

To respond to the increased enforcement costs generated by the digital environment, rightholders implemented DRM, a system of technological means designed to selfenforce copyright in the digital world. The form of market failure produced by high enforcement costs, sharpened by the digital environment, can be cured by DRM. However, DRM imposes higher up-front production costs for its implementation, which have to be balanced against the savings in enforcement procedures. Moreover, arguably DRM represents a barrier to the entrance in the market of new competitors. Paul Petrick for example, examining the music market, argues that DRM on the one hand is useful to fight piracy and lower transaction costs, and on the other hand reduces social welfare by raising barriers to access the market, therefore facilitating monopolistic behaviour (another market failure). These barriers are produced by the up-front cost of implementing DRM. ${ }^{66}$ In short, the enhancement of profits would make the

\footnotetext{
${ }^{65}$ Problem tackled also by Goldstein. He warns that computer retrieval systems or clearing houses contribute to decrease substantially transaction costs. See P Goldstain, Goldstein on Copyright, (3rd ed, Wolters Kluwer, New York 2013) vol II, 7.

${ }^{66}$ In contrast, Rosenblatt foresees a decrease in the cost of DRM. He states that ' $[t]$ he problem of the cost of DRM should recede over time as DRM becomes more and more bundled into value-added services that have tangible benefits for users'. See B Rosenblatt, 'Integrating DRM with P2P Networks: Enabling the Future of Online Content Business Models', (2003) 19 November 2003 on <drmwatch.com>accessed 16 April 2014.
} 
implementation of DRM a stimulus to competition, but the cost of DRM implementation could turn out to hinder competition because it is prohibitive for small music firms. ${ }^{67}$ As a general consequence, the supply of expressive works to consumers would decrease. ${ }^{68}$

Also in the digital environment customers' misinformation, transaction costs, market power, and externalities (market failures) undermine fair competition. ${ }^{69}$ In sum, the Digital Era creates both advantages and disadvantages for producers of copyright works. Among the advantages are: a) lower right clearance costs; b) lower negotiation costs; c) higher potential for price differentiation. A crucial disadvantage however is the rise in free-riding behaviours with consequent increase of enforcement costs. Conversely, the digital environment creates only advantages for consumers, as it multiplies the possibilities of accessing and and using copyright works.

DRM as well produces advantages and disadvantages for rightholders: it lowers enforcement costs; it lowers negotiation costs (by facilitating the identification of rightholders); and it facilitates price differentiation. Interestingly, DRM brings advantages and disadvantages also to users of copyright works. On the one hand it facilitates price discrimination and on the other hand, by allowing rightholders to control every access to and use of digital works, it stifles the enormous potential offered by the digital environment to new creative processes.

DRM, in sum, helps internalising the externalities of transactions involving digital copyright works by transferring on the parties involved in the transactions its costs and benefits, and by reducing spillovers to the minimum. It is therefore a rather efficient way to deal with market failures. The problem is that DRM reduces also positive

\footnotetext{
${ }^{67}$ Petrick (n 48) 28.

68 ibid, 14.

${ }^{69}$ See section 2.2 above.
} 
externalities, i.e. occasional leaks of copyright works that enhance the free circulation of culture. For example, DRM can stem the diffusion of information among consumers, by hindering the lending of music. It can forbid donating the work to a library or a school. It can inhibit derivative works. ${ }^{70}$ In sum, it can disrupt copyright's direct social function by privileging the so-called private ordering. ${ }^{71}$ I this way, DRM enhances, rather than suppressing, market distortions.

In conclusion, DRM has the potential to simultaneously reduce some market failures while worsening others. Social-inhibiting effects of DRM should therefore been limited by developing users allowances in accordance. Further research is required on technological solutions accommodating this need.

\subsection{Economic Justifications of Copyright Exceptions}

The legal-economic literature, starting from the Chicago law school, discussed at length the justification of copyright exceptions as a legal response to forms of market failure. According to Wendy Gordon, for example, only in the presence of market failure, i.e. because of insurmountable transaction costs or unjustified (not based on economic reasons) refusal of the copyright owner to grant the license, the fair use exemption is justifiable. ${ }^{72}$ As other neoclassical economists, Gordon claims that an efficient market will give balanced protection to the rights of all copyright players. ${ }^{73}$ As a consequence, copyright exceptions (in the US: fair use) can be implemented within

\footnotetext{
${ }^{70}$ See L Pallas Loren, 'Redefining The Market Failure Approach to Fair Use in an Era of Copyright Permission Systems' (1997) 5 J Intell Prop L 13, 48.

${ }^{71}$ See generally J Cohen, 'Copyright and the Perfect Curve', (2000) 53 Vand L Rev 1799.

${ }^{72}$ To be exact, market failure is only one of the conditions for the application of Fair use. The others are the fact that a transfer to the defendant is socially desirable, and that the use do not cause substantial injury to author's incentive. ibid, 1801.

${ }^{73}$ This is however an older finding by Wendy Gordon (Gordon 1982, n 9). In the following work (W Gordon, 'A Property Right in Self-Expression: Equality and Individualism in the Natural Law of Intellectual Property', (1993) 201 Yale L J 1533) she reaches different conclusion, by recommending for intellectual property owners a right 'less than property'.
} 
copyright law only when justified by some form of market failure. Courts of law, Gordon argues, should perform a three-element test before enforcing copyright limits: 1) occurrence of a market failure; i.e. the possibility for consensual bargain must be somehow broken down. For example, the user cannot find the good through normal channels in the market or the rightholder refuses to license the work for non-economic reasons. ${ }^{74}$ 2) Balancing injury and benefit; this is the classic trade-off of copyright, between reward of the author and diffusion of the work. The court, according to Gordon, has to assess whether the work is more valuable in the hands of the owner or in the hands of the user. ${ }^{75}$ 3) The substantial injury hurdle. The court has to assess whether the infringement causes an injury to the owner such that she will lose any incentive to produce copyright works. ${ }^{76}$ All the above instances have to be true for a court to allow the fair use exception.

Similarly, Robert Merges sees fair use as a corrective for those situations in which externalities cannot be fully internalized. ${ }^{77} \mathrm{He}$ discusses for example the exception for parody, which has a special social value, because it allows critical debate. This particular copyright exception is grounded on freedom of expression. However, to protect their image, rightholders may refuse to license the work for use in a parody. This is a typical case of refusal to sign a contract for non-economic reasons (a market failure). The protection of the exception for parody in this case would require compulsory licensing $;^{78}$ but the protection is justified only to the extent to which a market failure occurs.

\footnotetext{
${ }^{74}$ Gordon (n 9) 1541.

75 ibid, 1545.

76 ibid, 1556.

${ }^{77}$ See generally RP Merges, 'Are You Making Fun of Me?: Notes on Market Failure and the Parody Defense in Copyright' (1993) 21 AIPLA Q J 305-312.

78 ibid, 306.
} 
The Digital Era gave those market-driven theories a further boost. The digital environment offers remarkable opportunities to fasten and secure licensing practices. In fact, several government and corporate policies are in the process of being implemented to take advantage of the new opportunities, such as the Copyright $\mathrm{Hub},{ }^{79}$ the digital copyright exchange, ${ }^{80}$ and Licenses for Europe ${ }^{81}$ Robert Merges states that in the digital environment the possibilities of market failure are greatly reduced. Negotiation costs and enforcement costs are lowered thanks to the implementation of technological protection measures. Compulsory licensing, which is comparatively more expensive than technological protection measures, is not necessary. Property rights, contracts, and markets have to be left free to address the issues caused by the digital environment, because those are the most efficient means ${ }^{82}$ to produce social welfare.

Tom W. Bell had argued something similar years before. He claimed that new technologies will allow creators and producers to bill customers for their use of copyright works, allowing free (but "fared", i.e. subject to a fee) access to expressive work, in a pay-per-use regime. ${ }^{83}$ Bell argued that we should leave the market to dictate the rules for the new balance between underproduction and underutilization of copyright works, which is the historical trade-off of copyright law. ${ }^{84}$ While lack of protection,

\footnotetext{
${ }^{79}$ The Copyright Hub is a portal sponsored by the UK creative industries, which will provide links to databases in order to make copyight licensing easier and cost-effective. See http://www.copyrighthub.co.uk/

80 This is a licensing hub envisaged by the UK government to facilitate digital copyright licensing. See generally B Longo, 'Is There Any Digital Copyright Exchange in Your Future?' (April 16, 2012). Aslib's 'Managing Information' Magazine, 19 (2012), n. 3, p. 28-30. Available at SSRN:

http://ssrn.com/abstract=2197857, and the DCE feasibility studies at http://www.ipo.gov.uk/hargreavescopyright-dce accessed 16 April 2014.

${ }^{81}$ License for Europe is an initiative of the EU Comission to promote a structured dialogue among copyright stakeholder, in order to facilitate cross-border copyright licensing in the digital age. See <http://ec.europa.eu/licences-for-europe-dialogue/en/content/about-site> accessed 16 April 2014 .

${ }^{82}$ RP Merges, 'Compulsory Licensing vs. the Three "Golden Oldies", Property Rights, Contracts, and Markets', Cato Institute, Cato Policy Analysis No. 508, (15/01/2004) at 〈http://www.cato.org/pub $>$ accessed 25 April 2014.

${ }^{83}$ See generally Bell (n 4).

${ }^{84}$ For an overview of the economics of copyright law, see CPB Netherlands report (n 59) section 4.4.
} 
(hence lack of incentives) prompts an underproduction of copyright works, an excessive protection prompts an underutilization of them. Tipping the scale on either side would be inefficient, from a market prospective. However, an unregulated market would spontaneously strike this balance.

In contrast, Lydia Pallas Loren maintains that even an efficient negotiation process between owners and users of copyright works, enabled by DRM, would not displace the role of fair use in copyright. In fact, the purpose of fair use is "to permit uses whose external benefits outweigh any perceived damage to the creators' incentive to create, regardless of whether the copyright owner would like to be paid for a particular use and regardless of whether the copyright owner has established a system to collect such payments". ${ }^{85}$ For Pallas Loren, therefore, whether or not the parties are ready to negotiate an agreement, which would satisfy the conditions of an efficient market, it is in some cases irrelevant. Only the benefit for the public and its ability to outweigh eventual damages to creators has to be assessed.

Similarly, Julie Cohen argues that the neoclassical model is not suitable to the promotion of progress, which is the purpose of copyright protection. This is because the creative process is unpredictable, and cannot be harnessed by the rules of the neoclassical economic model ${ }^{86}$ In other words, the ability of authors to produce further copyright works does not depend on the incentive they receive, but rather on their inspiration. The variable of the inspiration of authors is not accounted for in the neoclassic model, nor could it be, because it is unpredictable.

Even Wendy Gordon, in her later work, states that fair use justifications can be divided in two categories: one deriving from market "malfunctions" and another

\footnotetext{
${ }^{85}$ See Pallas Loren (n 69) 48.

${ }^{86}$ Cohen (n 70) 1800.
} 
deriving from "inherent limitations" ${ }^{87}$ If the market were efficient, we could leave copyright unregulated. The law of the market would optimally allocate the welfare deriving from it. However, since the market is not efficient we need to implement regulations to correct its malfunctions, and that is why copyright exceptions are necessary.

Inherent limitations instead are those market failures that we would not leave to the laws of the market, even if the market were efficient. We do so because they have a particular social value, and therefore have to be regulated on the basis of non-economic principles. An example of inherent limitations, outside of copyright law, is represented by the prohibition on commerce with parts of the human body. ${ }^{88}$ Although the contractors might be perfectly willing to find an agreement on the sale of a part of a human body, this is considered immoral in most cultures, and it is forbidden by law. Similarly, an act of access to a copyright work with a particular social value should be allowed, despite the loss for the author.

The argument above suggests that the traditional interpretation of the neoclassical model identifying a justification for copyright exceptions only in some cases of market failure (i.e. in the absence of the possibility of a free negotiation) should be abandoned. ${ }^{89}$ Most recent literature, both legal and economic, argues that "social" variables have to be considered alongside economic principles. ${ }^{90}$ Furthermore, social variables have the potential to create new forms of market failures, which have to be

\footnotetext{
${ }^{87}$ W Gordon, 'Excuse and Justification in the Law of Fair Use: Transaction Costs Have Always Been Only Part of the Story' (2003) 50 J Copyright Soc USA 149, 151-152.

${ }^{88}$ ibid. Gordon explains more in depth the difference between market malfunctions and inherent limitations with the help of the distinction between 'excuse' and 'justification' in criminal law. The concept of excuse needs a fact pattern in which, if circumstances were different, we would like to punish the infringer; but since they are not, we excuse her instead. The concept of justification, on the contrary, attributes no role to external circumstances. However they might be, we (the community) decide that we are happy of the behaviour of the 'infringer'.
}

${ }^{89}$ See Merges (n 76) and Bell (n 4).

${ }^{90}$ See Pallas Loren (n 69) and Gordon (n 86). 
addressed, as other market failures, by legislation. In the field of copyright this action of copyright legislation takes the form of copyright limits: duration, exhaustion, and exceptions (fair use).

In this framework, the role of DRM appears two-folded: on the one hand DRM by internalising transaction costs addresses those that Gordon calls "malfunctions" of the market. On the other hand, however, DRM does not address the "inherent limitations" of the market. On the contrary, undifferentiated restricted access to copyright goods would impede the legitimate exercise of the some of the entitlement of the user provided by copyright law, hence committing a breach of law. Indiscriminate legal protection of DRM would be paradoxical: it would allow legal protection to illegal behaviour, without the support of legal justifications.

Legally defining the boundaries of DRM is therefore necessary to implement technical locks operating within copyright law, that is, within the respect of copyright limits and exceptions. Identifying and mandating technical standards in this sense should be the object of future interdisciplinary research aimed at informing copyright policies.

\section{The Social Justifications of Copyright}

The doctrines examined above show a copyright system that indirectly achieves social goals through the protection of the author/rightholder. However, some commentators argue that social goals must be directly pursued by copyright legislation. This implies that the protection of the author comes second to the protection of the public. In practical terms, this means that the public is allowed every use of copyright works that does not damage the author directly and substantially. Patterson and Lindberg, for example, maintain that copyright has been invented firstly and mainly to enhance the learning process of the community at large. It does so by promoting the circulation of culture and the transmission of knowledge. Similarly, Neil Netanel claims 
that copyright is a direct vehicle of democracy, by boosting exchange of ideas and communication of thoughts. Both these arguments suggest an interpretation of copyright law aimed at protecting the public rather than the authors of copyright works.

\subsection{Copyright to Protect the Learning}

Ray Patterson and Stanley Lindberg argue that copyright history should be the base for a correct interpretation of copyright law. Historically, copyright protection was envisaged to protect book publishers from unauthorised publication of works. However, the first copyright legislation, the Statute of Anne, ${ }^{91}$ was subtitled "an act for the encouragement of learning". This suggests that besides the moral right of the author, and the financial rights of the exploiter of the work, a third right is envisageable: the 'right of learning' of the public..$^{92}$

Patterson and Lindberg argue that the exclusive right of the author is not a right but a privilege, which originates from a deal between the author and the public. According to the terms of this deal on the one hand the author creates the work for the public to enjoy it and to learn from it. The public, on the other hand, allows the author to exercise monopolistic control over the financial exploitation of the work for a limited period of time. ${ }^{93}$ After that time, the expressive work is freely available and exploitable by the entire community. Ignoring copyright limits (not only copyright duration but also copyright exceptions or fair use) represents a breach of contract. An excessive copyright interferes with freedom of expression and communication, which forms the

\footnotetext{
91 The Statute of Anne, c. 19 (1710) 'An act for the encouragement of learning, by vesting the copies of printed books in the authors or purchasers of such copies, during the times therein mentioned'. Available at http://avalon.law.yale.edu/18th_century/anne_1710.asp accessed 14 April 2014.

92 Patterson and Lindberg (n 5) 49. Patterson and Lindberg recognize a moral rights for the author, marketing rights for the entrepreneur, and learning rights for the user.

93 ibid, 236, arguing that 'The grant of copyright by Congress is not a right but a privilege[...]those who accept this privilege assume an obligation to fulfil the constitutional purpose of copyright, the promotion of learning'.
} 
underpinning of copyright limits. ${ }^{94}$ The owners, according to these commentators, should be subject to restrictions and privileges at the same time. ${ }^{95}$ They enjoy the fair reward for their creation/divulgation, but they have the responsibility to ensure the entitlements of the public. As they put it: "copyright entails the right of public access as a quid pro quo for the benefit received by the copyright owner in the statutory grant of monopoly rights". 96

Yet, Patterson and Lindberg argue, in practice the economic interests of rightholders are the objective of current copyright legislation, ${ }^{97}$ despite repeated claims for protection of culture and information. ${ }^{98}$ Even the civil law-derived moral rights, which are also increasingly implemented in common law countries, are often used only as a screen to disguise the economic interests of the copyright owner. ${ }^{99}$ This is evidenced by the current legal protection of works whose ability to express the personality of the creator is at least debatable, as for example software and database. ${ }^{100}$

In sum, current copyright law resources to several contrivances to trump public entitlements and to skew copyright protection in favour of the right holders. ${ }^{101}$

\footnotetext{
94 ibid, 132. For Patterson and Lindberg, copyright poses a threat to free speech as an 'instrument that enables one to control the flow of information'.

${ }^{95}$ It may be useful, in this case, a construct of civil law, the "power-duty".

${ }^{96}$ Patterson and Lindberg (n 5) 69.

${ }^{97}$ The authors state: 'as century progressed, the regulatory aspects of copyright were increasingly subordinated to proprietary aspects'. ibid, 88.

${ }^{98}$ Claims of protection for culture and knowledge are found also in recent copyright legislation. See for example Council Directive 2001/29/EC (n 37) Recital 9: 'Any harmonisation of copyright and related rights must take as a basis a high protection, since such rights are crucial to intellectual creation. Their protection helps to ensure the maintenance and development of creativity in the interests of authors, performers, producers, consumers, culture, industry and the public at large'. See also Recital 14: 'This Directive should seek to promote learning and culture by protecting works and other subject-matter while permitting exceptions or limitations in the public interest for the purpose of education and teaching'. See also the U.S. Constitution, stating that the goal of copyright is 'to promote the Progress of Science and useful Arts'. U.S. Const. art I, para. 8, cl. 8.

${ }^{99}$ See section 2.6 below.

${ }^{100}$ Patterson and Lindberg (n 5) 136-137.

101 ibid. In contemporary copyright law, according to the authors, there are fictions and fallacies which threaten the fundamental learning purpose of copyright. As examples of fictions they recall the
} 
Yet, the digital environment opens unforeseeable scenarios for access to culture and education. Internet platforms allowing access to content make education available to everybody in the world. People traditionally excluded from more than elementary education can now access, read, listen to expressive works with only a fraction of the investment that would be necessary in the analogue environment. E-learning infrastructures, digital libraries, virtual laboratories make this possible.

Strict copyright protection and implementation of DRM would dispel this enormous potential.

Expanding the protection for DRM automatically restricts the possibility for the public to use existing works; and the reduced possibility of accessing cultural works will decrease access to education and will hinder inspiration for prospective producers of new intellectual works. ${ }^{102}$

The solution is simple: a correct interpretation of the rationale behind copyright will restore the balance between the protection of rightholders and users of copyright works, and it will allow the public to take advantage of the opportunities offered by the new technologies.

\subsection{The Democratic Paradigm.}

Another theory centralises the role of the public in copyright protection. Neil Netanel claims that the circulation of culture is a direct function of copyright. Allowing free flow of information is instrumental to the public discourse and ultimately necessary to foster democracy.

classification of corporations as authors, under the work-for-hire doctrine, and the copyright protection to items that most people would not consider writings, like software and database. The fallacies are the notions that the author is the primary beneficiary of copyright and that copyright is the private property of the author.

\footnotetext{
102 Many commentators share Patterson and Lindberg concerns on the matter. See generally MS Nadel, 'How Current Copyright Law Discourages' Creative Output: The Overlooked Impact of Marketing', (2004) 19 Berkeley Tech L J 785-855; DL Zimmerman, 'Copyright In Cyberspace: Don't Throw Out the Public Interest with the Bath Water', (1994) Ann Surv Am L 403; and P Samuelson, 'Mapping The Digital Public Domain: Threats And Opportunities’, (2003) 66 Law \& Contemp. Probs. 147.
} 
In contrast to neoclassical theories, Neil Netanel theorizes the 'democratic paradigm'. He argues that "while copyright may operate in the market, copyright's fundamental goals are not of the market". ${ }^{103}$ In essence, an unregulated market has the potential to create inequality between copyright players, because the efficient allocation of resources theorised by neoclassic economists is unlikely to occur in the real world, due to the abuse of dominant positions and the distorting action of lobbying groups. According to the democratic paradigm, copyright has two main functions: a) a production function, ${ }^{104}$ which spurs creators to provide information, education, communication, and culture in general; b) a structural function, ${ }^{105}$ which allows creators to emancipate from patrons. This emancipation cannot be pursued by replacing patrons with governments or corporations because this would trigger undue influence from political or financial interests; ${ }^{106}$ whereas "copyright constructed in accordance with the democratic paradigm would enhance expressive pluralism and diversity, not only by supporting an independent expressive sector, but also by imposing limits on the proprietary control over cultural works". ${ }^{107}$ Scope and duration of copyright, therefore, are envisaged on the one hand to protect the incentives of copyright owners and on the other hand to leave sufficient room for copyright democracy-enhancing goals.

The democratic paradigm critically discusses a few strongholds of economic theory. For example, Netanel doubts that price differentiation would cover the full range of consumers, as neoclassicism maintain. ${ }^{108}$ For example, several studies show that

\footnotetext{
${ }^{103}$ Netanel (n 5) 341.

104 ibid, 348-351.

105 ibid, 352-362.

106 ibid, 359.

107 ibid, 360. This point is supported also by MJ Roe, 'Chaos and Evolution in Law and Economics' (1996) 109 HLR 641, 361.

${ }^{108}$ See Netanel (n 5) 335. He claims: 'There is little evidence, if any, that a finely tuned pricing system, built upon a broad proprietory copyright, would direct investment to diverse audiences any more effectively than a more balanced copyright regime'.
} 
consumer choices are influenced by taste and fashion and "do not reflect the full array of potential audience receptivity". ${ }^{109}$ Entertainment producers, for obvious lucrative reasons, invest in products that have the potential to meet the taste of the largest share of consumers. This favours the diffusion of entertainment products that do not necessarily enrich our cultural patrimony, while minority arts are subsidized by public funds. It follows that economic mechanisms are not mainly set by the ability of the producer to satisfy consumer demand, but rather by "arbitrary conditions, local evolution and path dependence". 110

Similarly to Patterson and Lindberg, Natanel's theory suggests that a copyright legislation designed or interpreted according to the democracy-enhancing function of copyright would improve the balance between owners and users of copyright works. Legislators in essence should be true to their claims to pursue the public interest though the enhancement of culture, the diffusion of information, and the promotion of democratic discourse; ${ }^{111}$ and they should implement specific legislation to pursue these goals directly.

The digital environment, as demonstrated for example by YochaiBenkler, is particularly suitable to express and enforce democratic discourse. Benkler suggests that strategic consumer behaviour prompted by discussions on Internet social networks can have the power to "punish" anti-competitive behaviour of technology producers. ${ }^{112}$ The circulation of ideas, therefore, enhanced by new technological means, can be considered a step forward on the path of democratic discourse. This implies that access barriers cannot but set back this important function of copyright.

\footnotetext{
109 ibid, 333.

${ }^{110}$ Roe (n 106) 361.

111 ibid, 359.

${ }^{112}$ See Y Benkler 'The Technological is Political: Access to an Open Information Environment', at iLaw conference Turin 25-27 May 2005.
} 
The role of DRM in this scenario is crucial. Access to information and culture, instrumental in the democratic discourse, will be seriously hindered in a digital environment in which DRM is implemented on a large scale. Strict access restrictions can only decrease the circulation of copyright works, thus lowering access to culture and information.

Recent history has shown that unlimited access to information thanks to the Internet in countries with limited or no democracy has induced a cultural change leading to a political revolution. ${ }^{113}$ A DRM system taking into account the democracy-enhancing function of copyright should implement technological protection measures with legally controlled access restrictions. This in practice might involve broad access allowances to copyright works and very limited usage restrictions.

\section{Conclusion}

The digital environment did not change the philosophy behind copyright protection. Beyond apparent divergence, both Locke's and Hegel's principles recognise the social function of copyright. However, the easy reproduction and retransmission of digital works has caused a proliferation of free-riding behaviours: a "reaping by who has not sowed". ${ }^{114}$ Against this wave of infringement, right-holders raise a barrier: DRM. But the Lockean proviso can be inferred to enjoin right-holders to leave "enough and as good" of the common to the public. In this perspective, strong intellectual property rights are not justifiable because the public function of copyright prevails over the private interests: the barrier needs to be lifted under certain circumstances.

\footnotetext{
${ }^{113}$ While dictatorial regimes need secrecy to thrive despite blatant violation of human rights, the Internet and its social network allow unprecedented monitoring and denunciation of such violation. See P Alston and C Gillespie (2012) 23(4) Eur J Int Law 1089, 119.

${ }^{114}$ See Section 2.1 above.
} 
Economic theories claim that an efficient market is the only source of public welfare. ${ }^{115}$ However, for the market to work properly, transaction costs need to be erased, together with market power, imperfect information, and externalities. ${ }^{116}$ Copyright law is devised to cure some market imperfections arising in the context of expressive works. Yet, the digital era could threaten the efforts of copyright legislation. High enforcement costs are a consequence of the easiness and quality of digital reproduction. DRM addresses this issue by lowering the cost of copyright enforcement. But DRM can also produce market dysfunctions, by forbidding the entrance of new competitors in the market. Moreover, DRM has the potential to erase positive externalities, which are beneficial for the circulation of culture.

Copyright exceptions, according to a common interpretation of neoclassical economic theory, are justified by high transaction costs. They create duty-free areas where negotiating a licence between the owner and the user would be too costly. However, from another point of view copyright exceptions protect the public interest in the presence of inherent limitations of the market. ${ }^{117}$ Therefore, technology must not erase copyright exceptions. It has to comply with them.

Copyright economic justifications indirectly protect the interest of the public while directly protecting copyright owners. However, according to some copyright scholars the public should be directly protected by copyright. The fist and direct goal of copyright should be to encourage learning and to promote democratic discourse. The protection of the author is justified only to the extent that it allows the achievement of this important goal, which can be pursued in practice only by implementing high access allowances to copyright works. The digital environment is ideal to enhance access to

\footnotetext{
${ }^{115}$ See Section 2.2 above.

${ }^{116}$ See the Coasian theory, in Netanel (n 5) 312.

${ }^{117}$ See Pallas Loren (n 69) and Cohen (n 70).
} 
information and - hence- democracy. DRM implementation should take place within legal limits so to preserve the democratic discourse.

This divergence between economical and social justification of copyright has animated a decade of academic debate, and it is nowhere to be settled. ${ }^{118}$ However, a common underpinning to both copyright exclusive rights and copyright limits is the stimulus to culture and knowledge through a balanced protection of owners and users of copyright works. This point does not appear to be challenged by the advent of the Digital Era. But while copyright adapts to the digital environment, technical solutions need to be explored to achieve digital protections respecting copyright philosophical, economical and social justifications. answers to the most crucial questions. See for example Merrill and Raduchel (n 63) 13. 